\title{
Oropharyngeal (p16-Negative) Cancer Clinical Regional Lymph Nodes TNM Finding v8
}

National Cancer Institute

\section{Source}

National Cancer Institute. Oropharyngeal (p16-Negative) Cancer Clinical Regional Lymph Nodes TNM Finding v8. NCI Thesaurus. Code C132935.

A clinical finding about one or more characteristics of oropharyngeal (p16-negative) cancer, following the rules of the TNM AJCC V8 classification system as they pertain to staging of regional lymph nodes. 